\title{
Association between left ventricular hypertrophy and erythrocyte sodium-lithium exchange in normotensive subjects with and without NIDDM
}

\author{
M. J.Sampson ${ }^{1}$, E. Denver ${ }^{1}$, W.J.Foyle ${ }^{1}$, D. Dawson ${ }^{2}$, J.Pinkney ${ }^{1}$, J. S. Yudkin ${ }^{1}$ \\ ${ }^{1}$ Department of Medicine, University College London Medical School, Whittington Hospital, Highgate Hill, London, UK \\ ${ }^{2}$ Department of Cardiology, Whittington Hospital, Highgate Hill, London, UK
}

\begin{abstract}
Summary The determinants of left ventricular mass in normal control subjects and subjects with non-insulindependent diabetes (NIDDM) are ill-defined. We therefore recorded M-mode and pulsed Doppler echocardiograms and 24-h ambulatory blood pressure in 57 normotensive subjects, 34 with NIDDM and 23 matched non-diabetic control subjects. Measurements of erythrocyte sodium-lithium countertransport, plasma angiotensin II, plasma and platelet catecholamines and fasting plasma insulin were also made. Six control subjects ( $26 \%)$ and 15 diabetic subjects (44\%) had some degree of left ventricular hypertrophy. Subjects with left ventricular hypertrophy $(n=21)$ had an elevated mean rate of sodium-lithium countertransport $\left(0.40 \pm 0.13\right.$ vs $0.31 \pm 0.09 \mathrm{mmol} \cdot 1^{-1}$ $\cdot \mathrm{h}^{-1} ; p<0.01$ ), parallel differences being observed in both the diabetic and control groups. Twelve of the subjects with left ventricular hypertrophy (57\%) had elevated rates of sodium-lithium countertransport compared to only seven $(19 \%)$ of those
\end{abstract}

without $(p<0.05)$. There was no consistent difference between those with and without left ventricular hypertrophy in any other clinical or biochemical variable. Multivariate analysis, with the presence or absence of left ventricular hypertrophy as the dependent variable, demonstrated that the maximal rate of sodium-lithium countertransport was the only variable that independently contributed to left ventricular hypertrophy (partial $r=0.35 ; F_{1.55}=7.74 ; p=$ $0.007)$. This study demonstrates for the first time an association between left ventricular hypertrophy and erythrocyte membrane cation transport that is independent of hypertension, is present in both diabetic and non-diabetic groups, and may represent a link between elevated rates of membrane sodium transport and cardiovascular risk. [Diabetologia (1995) 37: 454-460]

Key words Left ventricular hypertrophy, diabetes mellitus, sodium-lithium countertransport.
Left ventricular hypertrophy, when derived from standard M-mode echocardiograms, is a remarkably powerful predictor of future cardiovascular events $[1,2]$. This predictive power has been demonstrated in both normotensive and hypertensive populations $[1,3]$, and in both men and women [4]. Subjects with

Received: 14 June 1994

and in revised form: 9 September 1994

Corresponding author: Dr. M.J.Sampson, Norfolk and Norwich Hospital, Norwich, Norfolk, NR1, UK

Abbreviations: Na-Li CT, Sodium-lithium countertransport; LVH, left ventricular hypertrophy; AER, urinary albumin excretion rate. non-insulin-dependent diabetes (NIDDM) suffer from cardiovascular disease at a rate in excess of that predicted by known cardiovascular risk factors [5], and there is some limited evidence that NIDDM is independently associated with an increased left ventricular mass [6].

Age, body mass index and blood pressure all contribute to population variability in left ventricular mass [7], but the potential contributions of the renin-angiotensin system [8], plasma catecholamines [9], insulin and insulin resistance [10] and membrane cation transport [11] are well recognised, at least in hypertensive populations. NIDDM patients and non-diabetic subjects differ in many of these variables, but whether this contri- 
butes to differences in left ventricular mass is unknown.

The aims of this cross-sectional echocardiographic study were to compare the left ventricular mass of normotensive NIDDM subjects with matched nondiabetic control subjects and to examine the separate potential determinants of left ventricular mass in these two groups.

\section{Patients and methods}

Hospital Ethical Committee approval and informed consent were obtained before we studied 34 subjects who fulfilled the World Health Organisation diagnostic criteria for NIDDM [12]. These subjects were recruited from an outpatient population (without regard to gender or ethnic origin), if they were 35 to 65 years old with a body mass index of less than $32 \mathrm{~kg} / \mathrm{m}^{2}$ and a blood pressure below $160 / 90 \mathrm{~mm} \mathrm{Hg}$. This initial blood pressure reading was taken by a single observer with a Hawksley random zero sphygmomanometer (Hawksley and Sons, Lancing, Sussex, UK). Three readings were taken on the right arm after 10-min supine rest, by a single observer, and a mean value calculated. In addition, all subjects had a normal 12lead electrocardiogram and were negative for macroproteinuria on urinalysis (Albustix, Ames, London UK). No subject had a history of treated hypertension or cardiac disease, and none had ever received insulin or any antihypertensive medication. In 13 subjects ( $38 \%$ ), adequate glycaemic control was maintained by dietary measures, while the remaining subjects received oral hypoglycaemic agents.

Twenty-three non-diabetic control subjects were recruited using the same criteria, except that all had a normal fasting blood glucose and a normal glycated haemoglobin. Control subjects were selected to ensure that the groups were comparable for gender, ethnic origin and body mass index.

Methods. All subjects underwent standard M-mode and pulsed Doppler echocardiography, 24-h ambulatory blood pressure monitoring and fasting venesection. All blood pressure and echocardiographic measurements were made by single observers who were unaware of the subjects' clinical state.

A more accurate measure of the pressure load on the left ventricle is given by $24-\mathrm{h}$ ambulatory blood pressure recording and "white-coat" hypertension is avoided [13]. All subjects underwent blood pressure monitoring with a Takeda TM 2420 system with measurements every 15 min during the day (08.00-22.00 hours) and every $30 \mathrm{~min}$ during the night (22.00-08.00). Mean systolic and diastolic blood pressures were calculated for the day, night and entire $24 \mathrm{~h}$.

Conventional M-mode echocardiograms were recorded using a mechanical scanner system (ATL-UMA) with a $3 \mathrm{MHz}$ duplex probe. Left ventricular measurements and left ventricular mass index (LVMI; $\mathrm{g} / \mathrm{m}^{2}$ body surface area) were calculated according to the Penn convention [14] and the upper limit of normal was taken as $131 \mathrm{~g} / \mathrm{m}^{2}$ and $100 \mathrm{~g} / \mathrm{m}^{2}$ (women). These widely accepted figures are based on the large population-based data of Levy et al. [15].

Pulsed Doppler echocardiograms were recorded simulta neously. This method measures peak left ventricular filling velocities during the early (E) and later atrial phase (A) of diastolic filling. An E : A ratio of less than 1.0 allows the separation of normal from abnormal angiographic diastolic filling in $93 \%$ of cases [16], and may suggest a less compliant left ventricle.
On fasting blood samples, plasma glucose concentrations was measured by a glucose oxidase method, glycated haemoglobin $\left(\mathrm{HbA}_{1}\right)$ by the Corning method (Corning 701 system, Ciba, Sussex, UK, normal range $6.5-8.5 \%$ ) total cholesterol and triglycerides by standard enzymatic methods (Technicon RA 1000 analyser, Technicon Instruments, Basingstoke, Hants, UK), HDL-cholesterol by a heparin-manganese precipitation technique, LDL-cholesterol by calculation from the Friedewald formula [17], plasma insulin using a specific twosite immunoradiometric method that does not react with proinsulin or its conversion intermediates [18] and plasma angiotensin II by radioimmunoassay [19]. Plasma noradrenaline and adrenaline and platelet noradrenaline were measured using a technique described previously [20]. Platelet catecholamines may give a more integrated measurement of circulating noradrenaline, avoiding rapid fluctuations seen in plasma levels [24]. Finally, the maximal rate of erythrocyte sodium-lithium countertransport ( $\mathrm{Na}-\mathrm{Li} \mathrm{CT}$ ) was measured in all subjects using a method modified from that described by Canessa et al. [22]. The upper limit of normal was taken to be $0.40 \mathrm{mmol} \cdot \mathrm{1}^{-1} \cdot \mathrm{h}^{-1}$ using this technique [22]. A single times overnight urine collection was obtained from the diabetic subjects to allow calculation of urinary albumin excretion rate (AER) using an in-house ELISA method [23].

\section{Statistical analysis}

All data are shown as a mean (SD) or as a median and range for non-normally distributed variables (plasma insulin and AER). Differences between the two groups or subgroups were analysed using unpaired Student's $t$-tests or Mann-Whitney $\mathrm{U}$ tests where appropriate. Differences in distributions between groups were analysed using chi-squared analysis. Simple linear and stepwise multiple regression analyses were carried out with $E$ : A ratio as a dependent variable. Because of the potential influences of gender and ethnicity on the raw data for left ventricular mass index, the presence or absence of left ventricular hypertrophy was used as the dependent variable in multivariate analyses. Diabetes and race were entered as dummy independent variables. The other independent variables included were age, body mass index, mean daytime, nighttime and 24-h blood pressures, insulin, glucose, angiotensin II, plasma noradrenaline and adrenaline, AER and sodium-lithium countertransport. Insulin concentrations and urinary AER were log transformed before inclusion in univariate and parametric multivariate analyses.

\section{Results}

Clinical features (Table 1). The clinical features of the diabetic and control groups are shown in Table 1 .

Blood pressure (Table 2). Mean 24-h systolic and diastolic blood pressures did not differ significantly between groups. Night and daytime mean blood pressures also did not differ between groups (data not shown).

Biochemical data (Table 2). There was by definition a significant difference in mean blood glucose concentrations and $\mathrm{HbA}_{1}$ between groups. Three of the 
Table 1. Basic clinical data in control and diabetic groups

\begin{tabular}{lll}
\hline & Control subjects & Diabetic subjects \\
\hline Number & 23 & 34 \\
Age (years) & $47.4(7.0)$ & $52.7(8.5)^{\mathrm{a}}$ \\
Sex (male : female) & $20: 3$ & $32: 2$ \\
$\begin{array}{l}\text { Race (C : A : AC) } \\
\text { Body mass index } \\
\left(\text { kg/m }{ }^{2}\right)\end{array}$ & $20: 1: 2$ & $23: 8: 3$ \\
$\begin{array}{l}\text { Current or } \\
\text { ex-smoker }(n)\end{array}$ & $24.2(2.2)$ & $25.7(2.7)$ \\
$\begin{array}{l}\text { Known parental } \\
\text { hypertension }(n)\end{array}$ & $4(26 \%)$ & $15(41 \%)$ \\
$\begin{array}{l}\text { Diabetes duration } \\
\text { (years) }\end{array}$ & - & $4(11 \%)$ \\
\hline
\end{tabular}

All data as mean and one SD. ${ }^{a} p<0.05$.

C, Caucasian; A, Asian; AC, Afro-Caribbean

34 diabetic subjects $(8.8 \%)$ had a urinary AER above $20 \mu \mathrm{g} / \mathrm{min}$.

There was no significant difference between groups for any biochemical measurement other than a lower plasma noradrenaline $(p<0.05)$ and a higher LDL-cholesterol $(p<0.05)$ in the diabetic group.

There was no significant difference between groups in mean rates of $\mathrm{Na}-\mathrm{Li} \mathrm{CT}$, but there was a significant difference in the distribution of individual values. Of the 23 control subjects, only 4 (17\%) had elevated rates of $\mathrm{Na}-\mathrm{LiCT}$, compared to 15 of the 34 diabetic subjects $(44 \% ; p<0.05)$.

Echocardiographic data (Table 2). There was no difference in mean left ventricular mass index between groups (Table 2 ). Of the control group, 6 subjects $(25 \%)$ had some degree of left ventricular hypertrophy, compared to $15(44 \%)$ of the diabetic group. This difference was not significant $(p=0.09)$. The mean $\mathrm{E}:$ A ratio was significantly lower in the diabetic group $(p<0.0001)$ and the heart rate significantly higher $(p<0.001)$.

Left ventricular hypertrophy (Tables 3 to 5). Table 3 shows the clinical, biochemical and echocardiographic data for the 21 subjects from both groups with left ventricular hypertrophy (LVH) and the remaining 36 patients without LVH. These groups did not differ regarding age, BMI, gender, ethnic origin mean 24-h systolic and diastolic blood pressures, $\mathrm{E}: \mathrm{A}$ ratios or in any measured biochemical variable. The most striking difference between groups was in the mean rate of $\mathrm{Na}-\mathrm{Li} \mathrm{CT}$, which was significantly higher in the group with LVH $(0.4 \pm 0.13 \varpi \sigma$ $\left.0.31 \pm 0.09 \mathrm{mmol} \cdot 1^{-1} \cdot \mathbf{h}^{-1} ; p<0.005\right)$. In addition, more than half of the group with LVH had elevated rates of Na-Li CT (12 of $21 ; 57 \%$ ) compared to only $19 \%$ of those without LVH ( 7 of $36 ; p<0.05$ ). These differences are summarised in Figure 1.
Table 2. Echocardiographic and biochemical characteristics of the control and diabetic subjects

\begin{tabular}{|c|c|c|}
\hline & Control subjects & Diabetic subjects \\
\hline Number & 23 & 34 \\
\hline $\mathrm{E}:$ A ratio & $1.47(0.46)$ & $1.0(0.29)^{\mathrm{c}}$ \\
\hline $\begin{array}{l}\text { Left ventricular mass } \\
\text { index }\left(\mathrm{g} / \mathrm{m}^{2}\right)\end{array}$ & $111.5(25)$ & $118.5(25)$ \\
\hline $\begin{array}{l}\text { Left ventricular } \\
\text { hypertrophy }(n)\end{array}$ & $6(26 \%)$ & $15(44 \%)$ \\
\hline $\begin{array}{l}\text { Heart rate } \\
\text { (beats per min) }\end{array}$ & $66(11)$ & $74(8)^{b}$ \\
\hline $\begin{array}{l}\text { Na-Li CT } \\
\left(\mathrm{mmol} \cdot 1^{-1} \cdot \mathrm{h}^{-1}\right)\end{array}$ & $0.32(0.11)$ & $0.37(0.11)$ \\
\hline Raised Na-Li CT (n) & $4(17 \%)$ & $15(44 \%)^{a}$ \\
\hline $\begin{array}{l}\text { 24-h systolic blood } \\
\text { pressure }(\mathrm{mm} \mathrm{Hg})\end{array}$ & $120.2(12.9)$ & $125.8(12)$ \\
\hline $\begin{array}{l}\text { 24-h diastolic blood } \\
\text { pressure }(\mathrm{mm} \mathrm{Hg})\end{array}$ & $75.3(6.2)$ & $77.4(8)$ \\
\hline $\begin{array}{l}\text { Plasma insulin } \\
(\mathrm{pmol} / \mathrm{l})\end{array}$ & $31.3(6.6-183)$ & $57.5(2.9-183)$ \\
\hline $\begin{array}{l}\text { Plasma angiotensin II } \\
(\mathrm{pmol} / \mathrm{l})\end{array}$ & $12.4(3.3)$ & $11.9(3.4)$ \\
\hline $\begin{array}{l}\text { Plasma noradrenaline } \\
(\mathrm{pmol} / \mathrm{ml})\end{array}$ & $1.9(0.6)$ & $1.5(0.7)^{\mathrm{a}}$ \\
\hline $\begin{array}{l}\text { Plasma adrenaline } \\
(\mathrm{pmol} / \mathrm{ml})\end{array}$ & $0.2(0.1)$ & $0.3(0.2)$ \\
\hline $\begin{array}{l}\text { Platelet noradrenaline } \\
\text { (pmol/mg) }\end{array}$ & $1.26(0.53)$ & $1.71(0.91)$ \\
\hline $\mathrm{HbA}_{1}(\%)$ & $6.9(0.8)$ & $10.2(2.0)$ \\
\hline $\begin{array}{l}\text { Fasting plasma glucose } \\
(\mathrm{mmol} / \mathrm{l})\end{array}$ & $5.1(0.9)$ & $10.3(3.9)$ \\
\hline $\begin{array}{l}\text { Total cholesterol } \\
(\mathrm{mmol} / \mathrm{l})\end{array}$ & $5.4(0.8)$ & $5.6(1.2)$ \\
\hline $\begin{array}{l}\text { HDL-cholesterol } \\
(\mathrm{mmol} / 1)\end{array}$ & $1.3(0.6)$ & $1.1(0.2)$ \\
\hline $\begin{array}{l}\text { LDL-cholesterol } \\
(\mathrm{mmol} / \mathrm{l})\end{array}$ & $3.0(1.2)$ & $3.6(1.0)^{2}$ \\
\hline Triglycerides (mmol/l) & $1.6(0.8)$ & $1.4(0.8)$ \\
\hline
\end{tabular}

All data as mean and one SD except for insulin levels (median and range). ${ }^{\mathrm{a}} p<0.05 ;{ }^{\mathrm{b}} p<0.01 ;{ }^{\mathrm{c}} p<0.0001$

The association between LVH and elevated mean rates of $\mathrm{Na}-\mathrm{Li} \mathrm{CT}$ was also evident in the diabetic group (Table 4). In the control group, the difference in mean Na-LI CT between those with and without LVH was less striking $(0.38 \pm 0.16$ vs $0.29 \pm 0.06$; $p=0.09$, Table 5). It is important to note that the subgroups with $\mathrm{LVH}$ did not differ consistently from those without regarding age, BMI, gender, ethnic origin, blood pressures, E : A ratio, glycaemic control, plasma insulin, catecholamines or plasma angiotensin II (Tables 4 and 5). Nor was there any significant difference in any lipid measurement between these groups. 
Table 3. Clinical and biochemical data for subjects with and without left ventricular hypertrophy

\begin{tabular}{|c|c|c|}
\hline & \multicolumn{2}{|c|}{ Left ventricular hypertrophy } \\
\hline & Present & Absent \\
\hline Number $(n)$ & 21 & 36 \\
\hline $\begin{array}{l}\text { Left ventricular mass index } \\
\left(\mathrm{g} / \mathrm{m}^{2}\right)\end{array}$ & $136.5(23.0)$ & $102.0(15.6)^{\mathrm{c}}$ \\
\hline Age (years) & $51.7(8.9)$ & $49.8(7.9)$ \\
\hline BMI $\left(\mathrm{kg} / \mathrm{m}^{2}\right)$ & $24.8(2.6)$ & $25.3(2.5)$ \\
\hline Sex (male : female) & $17: 4$ & $34: 2$ \\
\hline Diabetes & 15 & 19 \\
\hline Ethnic origin $(\mathrm{C}: \mathrm{A}: \mathrm{AC})$ & $17: 2: 2$ & $26: 7: 2$ \\
\hline $\mathrm{E}: \mathrm{A}$ ratio & $1.07(0.34)$ & $1.25(0.46)$ \\
\hline $\begin{array}{l}\text { 24-h systolic blood pressure } \\
(\mathrm{mm} \mathrm{Hg})\end{array}$ & $126.2(13.9)$ & $122.0(12.1)$ \\
\hline $\begin{array}{l}\text { 24-h diastolic blood pressure } \\
(\mathrm{mm} \mathrm{Hg})\end{array}$ & $76.9(8.6)$ & $76.7(6.5)$ \\
\hline Plasma insulin (nmol/l) & $59.4(29.5)$ & $53.3(43.7)$ \\
\hline Angiotensin II (pmol/l) & $11.4(3.4)$ & $12.6(3.3)$ \\
\hline $\begin{array}{l}\text { Platelet noradrenaline } \\
\text { (pmol/mg) }\end{array}$ & $1.27(0.78)$ & $1.68(0.85)$ \\
\hline $\begin{array}{l}\text { Plasma noradrenaline } \\
(\mathrm{pmol} / \mathrm{ml})\end{array}$ & $1.66(0.75)$ & $1.67(0.61)$ \\
\hline $\begin{array}{l}\text { Plasma adrenaline } \\
(\mathrm{pmol} / \mathrm{ml})\end{array}$ & $0.27(0.25)$ & $0.23(0.13)$ \\
\hline $\mathrm{Na}-\mathrm{Li} \mathrm{CT}\left(\mathrm{mmol} \cdot \mathrm{l}^{-1} \cdot \mathrm{h}^{-1}\right)$ & $0.40(0.13)$ & $0.31(0.09)^{\mathrm{b}}$ \\
\hline Raised Na-Li CT (n) & $12(57 \%)$ & $7(19 \%)^{\mathrm{a}}$ \\
\hline
\end{tabular}

\section{Relationships between variables}

$E:$ A ratio. Univariate analysis of the total study population $(n=57)$ demonstrated relationships between $\mathrm{E}: \mathrm{A}$ ratio and age $(r=-0.48 ; p<0.00001)$, systolic blood pressure $(r=-0.56 ; p<0.000001)$, heart rate $(r=-0.46 ; p<0.00001)$, presence of diabetes $(r=-0.53 ; p<0.00001)$, platelet noradrenaline $(r=0.35 ; \quad p<0.01)$, plasma insulin $(r=-0.29$; $p<0.05)$ and BMI $(r=0.23 ; p=0.08)$. Left ventricular mass index was not significantly related to the $\mathrm{E}: \mathrm{A}$ ratio. Multiple regression demonstrated that only systolic blood pressure, heart rate, diabetes and BMI were significant independent contributors to variability in $\mathrm{E}$ : A ratio (Combined $r=0.78$, adjusted $\left.R^{2}=58 \%, F=18.3 ; p<0.0001\right)$. Diabetes independently accounted for $8 \%$ of the total variability explained, and systolic blood pressure $18 \%$.

Erythrocyte Na-Li CT did not contribute to the presence or absence of diabetes on multivariate analysis.

Left ventricular hypertrophy. Multivariate analysis of the total population $(n=57)$, with the presence or absence of $\mathrm{LVH}$ as the dependent variable, demonstrat-
Table 4. Clinical and biochemical data for the diabetic subjects with and without left ventricular hypertrophy

\begin{tabular}{|c|c|c|}
\hline & $\begin{array}{l}\text { Left ventricular } \\
\text { hypertrophy }\end{array}$ & $\begin{array}{l}\text { Normal left } \\
\text { ventricular } \\
\text { mass index }\end{array}$ \\
\hline$\overline{\text { Number }(n)}$ & 15 & 19 \\
\hline $\begin{array}{l}\text { Left ventricular mass } \\
\text { index }\left(\mathrm{g} / \mathrm{m}^{2}\right)\end{array}$ & $139.1(20)$ & $101.0(16)^{\mathrm{c}}$ \\
\hline Age (years) & $53.1(5)$ & $52.4(9)$ \\
\hline $\mathrm{BMI}\left(\mathrm{kg} / \mathrm{m}^{2}\right)$ & $25.6(2)$ & $26.1(3)$ \\
\hline Sex (male : female) & $12: 3$ & $18: 2$ \\
\hline $\begin{array}{l}\text { Ethnic origin } \\
(\mathrm{C}: \mathrm{A}: \mathrm{AC})\end{array}$ & $11: 2: 2$ & $12: 6: 1$ \\
\hline $\begin{array}{l}\text { Diabetes duration } \\
\text { (years) }\end{array}$ & $6.7(5.5)$ & $6.9(5.4)$ \\
\hline $\mathrm{E}:$ A ratio & $0.97(0.31)$ & $0.99(0.25)$ \\
\hline $\begin{array}{l}\text { 24-h systolic blood } \\
\text { pressure (mm Hg) }\end{array}$ & $126.0(14)$ & $125.7(12)$ \\
\hline $\begin{array}{l}\text { 24-h diastolic blood } \\
\text { pressure }(\mathrm{mm} \mathrm{Hg})\end{array}$ & $78.3(10)$ & $76.6(7)$ \\
\hline $\mathrm{HbA}_{1}(\%)$ & $10.5(2.2)$ & $10.0(1.8)$ \\
\hline $\begin{array}{l}\text { Albumin excretion rate } \\
(\mu \mathrm{g} / \mathrm{min})\end{array}$ & $5.2(0.2-130.2)$ & $4.8(0.8-39.6)$ \\
\hline Plasma insulin (nmol/1) & $44.1(12.6-177)$ & $62.3(4.9-183.3)$ \\
\hline Angiotensin II & $10.9(3.3)$ & $13.4(3.2)$ \\
\hline $\begin{array}{l}\text { Plasma noradrenaline } \\
(\mathrm{pmol} / \mathrm{ml})\end{array}$ & $1.4(0.7)$ & $1.6(0.7)$ \\
\hline $\begin{array}{l}\text { Plasma adrenaline } \\
(\mathrm{pmol} / \mathrm{ml})\end{array}$ & $0.2(0.1)$ & $0.2(0.1)$ \\
\hline Platelet noradrenaline & $1.35(0.86)$ & $2.0(0.98)^{\mathrm{a}}$ \\
\hline $\begin{array}{l}\mathrm{Na}-\mathrm{LiCT} \\
\left(\mathrm{mmol} \cdot 1^{-1} \cdot \mathrm{h}^{-1}\right)\end{array}$ & $0.41(0.12)$ & $0.32(0.09)^{\mathrm{a}}$ \\
\hline Raised Na-Li CT (n) & $10(66 \%)$ & $6(31 \%)^{a}$ \\
\hline
\end{tabular}

All data as mean and one SD except for insulin and albumin excretion rate (median and range). ${ }^{\mathrm{a}} p<0.05 ;{ }^{\mathrm{c}} p<0.0001$

ed that $\mathrm{Na}-\mathrm{Li} \mathrm{CT}$ was the only variable that was significantly related to the presence of LVH $(r=0.35$; adjusted $\left.R^{2}=10.75 \% ; F_{1.55}=7.74 ; p=0.007\right)$. No other variable contributed to the presence of $\mathrm{LVH}$.

\section{Discussion}

It is well recognised that a minority of normotensive middle-aged subjects will demonstrate mild to moderate degrees of LVH [24]. What is novel about the present findings is that this subgroup with an increased left ventricular mass, who are potentially at an increased risk of future cardiovascular events [13], are characterised by elevated mean rates of $\mathrm{Na}-\mathrm{Li}$ $\mathrm{CT}$ and an increased frequency of elevated rates of Na-Li CT. This finding was evident in the total study population and in the diabetic group (Tables 3-5).

In the present study $26 \%$ of normotensive middleaged control subjects demonstrated mild degrees of 
Table 5. Clinical and biochemical data for the control subjects with and without left ventricular hypertrophy

\begin{tabular}{|c|c|c|}
\hline & $\begin{array}{l}\text { Left ventricular } \\
\text { hypertrophy }\end{array}$ & $\begin{array}{l}\text { Normal left } \\
\text { ventricular } \\
\text { mass index }\end{array}$ \\
\hline Number $(n)$ & 6 & 17 \\
\hline $\begin{array}{l}\text { Left ventricular mass index } \\
\left(\mathrm{g} / \mathrm{m}^{2}\right)\end{array}$ & $140.4(18)$ & $101.0(18)^{\mathrm{c}}$ \\
\hline Age (years) & $46.9(6)$ & \\
\hline BMI $\left(\mathrm{kg} / \mathrm{m}^{2}\right)$ & $24.6(1.8)$ & $23.0(2.7)$ \\
\hline Sex (male : female) & $4: 2$ & $16: 1$ \\
\hline Ethnic origin $(\mathrm{C}: \mathrm{A}: \mathrm{AC})$ & $6: 0$ & $14: 2: 1$ \\
\hline $\mathrm{E}:$ A ratio & $1.33(0.4)$ & $1.52(0.5)$ \\
\hline $\begin{array}{l}\text { 24-h systolic blood pressure } \\
(\mathrm{mm} \mathrm{Hg})\end{array}$ & $122.5(19.5)$ & $119.3(10.2)$ \\
\hline $\begin{array}{l}\text { 24-h diastolic blood } \\
\text { pressure }(\mathrm{mm} \mathrm{Hg})\end{array}$ & $72.7(3.4)$ & $75.8(6.9)$ \\
\hline Plasma insulin (nmol/l) & $61.8(27-109)$ & $28.6(7-184)$ \\
\hline Angiotensin II (pmol/l) & $12.3(3.9)$ & $11.8(3.3)$ \\
\hline $\begin{array}{l}\text { Plasma noradrenaline } \\
(\mathrm{pmol} / \mathrm{ml})\end{array}$ & $2.2(0.4)$ & $1.7(0.52)^{\mathrm{a}}$ \\
\hline $\begin{array}{l}\text { Plasma adrenaline } \\
(\mathrm{pmol} / \mathrm{ml})\end{array}$ & $0.40(0.3)$ & $0.24(0.1)$ \\
\hline $\begin{array}{l}\text { Platelet noradrenaline } \\
(\mathrm{pmol} / \mathrm{mg})\end{array}$ & $1.13(0.6)$ & $1.3(0.49)$ \\
\hline $\mathrm{Na}-\mathrm{Li} \mathrm{CT}\left(\mathrm{mmol} \cdot \mathrm{l}^{-1} \cdot \mathrm{hr}^{-1}\right)$ & $0.38(0.16)$ & $0.29(0.06)$ \\
\hline Raised Na-Li CT $(n)$ & $2(33 \%)$ & $2(12 \%)$ \\
\hline
\end{tabular}

All data as mean and one SD except for insulin (median and range). ${ }^{a} p<0.05 ;{ }^{c} p<0.0001$

LVH. The age-specific prevalence of LVH in the Framingham population, for subjects between 50 and 59 years old was $18 \%$ for men with systolic blood pressures between 130 and $139 \mathrm{~mm} \mathrm{Hg}$, and was 16$19 \%$ in the study population overall, using various diagnostic criteria for $\mathrm{LVH}$ [24]. In our population there was a trend towards a greater frequency of LVH in the diabetic subjects, of whom $44 \%$ were affected. Galderisi et al. [6] demonstrated that 42 women from the Framingham cohort, with predominantly NIDDM, had a significantly greater left ventricular mass index than 2349 women without, and that the presence of diabetes was an independent contributor to left ventricular mass. However, no data on group blood pressures were provided, although the presence of hypertension was controlled for in multivariate analysis. A trend towards an excess of LVH in normotensive diabetic subjects could reflect higher maintained nocturnal blood pressures in a group with autonomic dysfunction [25], and the diabetic patients in the present study did have higher mean heart rates which could indicate autonomic dysfunction. However, there was no difference in mean nighttime blood pressures between the diabetic and control group, or between those with and without LVH in this study.

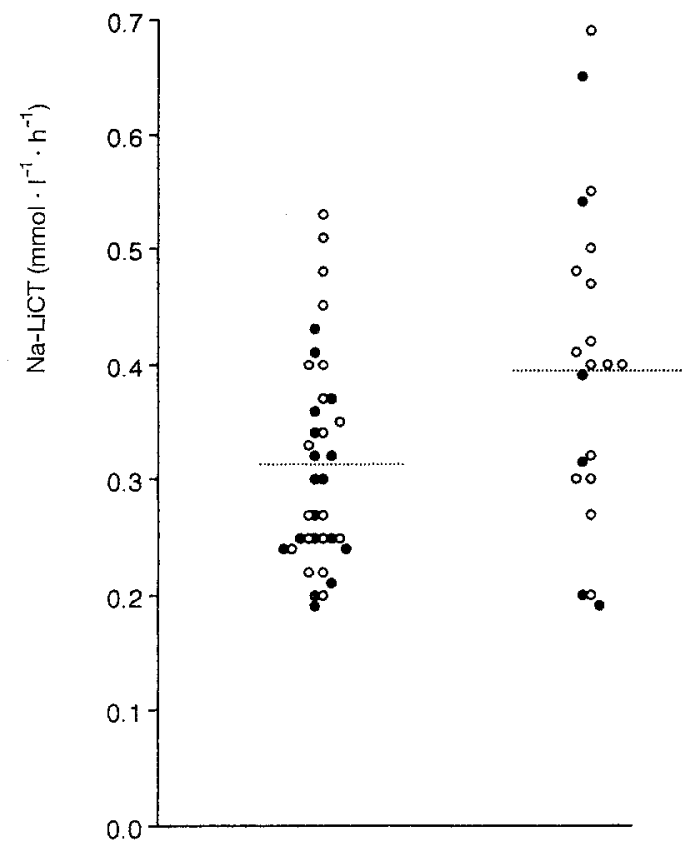

LV - $\quad L V+$

Fig. 1. Individual values for $\mathrm{Na}-\mathrm{Li} \mathrm{CT}$ in those with $(\mathrm{LV}+)$ and without $(\mathrm{LV}-$ ) left ventricular hypertrophy. Subjects with NIDDM are shown as $O$, and control subjects as $\bullet$. Difference between group means significant at $p=0.003$

The most striking finding in the present study was that subgroups with LVH differed from those without in having elevated rates of mean Na-Li CT, but not in any other measured clinical or biochemical variable. To the best of our knowledge, this is the first time that this has been clearly demonstrated in normotensive populations, although there are several reports of similar associations in various hypertensive groups [11, 26, 27]. This reported link between cardiac hypertrophy and more elevated rates of $\mathrm{Na}$ $\mathrm{Li} \mathrm{CT}$ in hypertensive groups does not necessarily indicate a direct association, and there are more physiologically plausible explanations. Hypertensive subjects with elevated rates of Na-Li CT could be a subgroup with slight elevations in blood pressure with the normal range before "true" hypertension developed $[28,29]$, or with a greater duration of hypertension [26] or with exaggerated pressor responses to exercise [27], all of which would account for an exaggerated hypertrophic response in this group.

The same finding in the present study, in unequivocally normotensive subjects, clarifies this relationship, and does suggest a direct link between LVH and membrane cation transport that is independent of hypertension.

The measurement of rates of erythrocyte Na-Li $\mathrm{CT}$ may reflect some function of membrane sodiumproton $\left(\mathrm{Na}^{+}-\mathrm{H}^{+}\right)$exchange, although this relationship remains to be clarified [30]. Elevated rates of membrane $\mathrm{Na}^{+}-\mathrm{H}^{+}$exchange may maintain a more 
alkaline intracellular $\mathrm{pH}$ [31] and promote protein synthesis [32], the intracellular mobilization of $\mathrm{Ca}^{++}$ in fibroblasts and smooth muscle cells may be $\mathrm{pH}$ dependent [33], and activity of protein kinase $\mathrm{C}$ may theoretically be enhanced by elevated rates of membrane Na-H exchange [34]. These roles in cell proliferation and stimulus-response coupling suggest that groups with elevated rates of $\mathrm{Na}-\mathrm{H}$ or $\mathrm{Na}-\mathrm{Li}$ CT represent a phenotype more likely to respond to any given stimulus with a growth response.

Two other studies have examined the association between membrane cation transport and left ventricular mass in normotensive populations. Semplicini et al. [35] found no difference in left ventricular mass index between normotensive insulin-dependent diabetic patients with and without elevated rates of Na-Li CT, although the group with elevated rates of Na-Li CT, did have a marginally greater interventricular septal width. The Tecumseh blood pressure study [28], examined 705 young subjects (mean age 31 years). The subgroup $(n=91)$ with elevated rates of Na-Li CT had a slightly but significantly lower left ventricular mass index, than those with normal rates, despite having higher blood pressures. The high transport group did however show evidence of ventricular remodelling, and as the authors point out, the pattern of hypertrophy could change as these subjects age. The subjects in the present study were on average about 20 years older than those in the Tecumseh study.

In normotensive subjects LVH has repeatedly been shown to predict the later development of hypertension [36, 37], and the children of hypertensive adults have a greater left ventricular mass than the children of normotensive adults [38], suggesting an inherited component to variability in left ventricular mass. Much of the variability in Na-Li CT is also inherited [39], and the present study makes it tempting to speculate that elevated rates of $\mathrm{Na}-\mathrm{Li} \mathrm{CT}$ are the bridge between LVH in normotensive subjects and the later development of hypertension. However, this can be answered only by long-term prospective studies.

Although there has been great interest in the role of catecholamines, angiotensin II and insulin as potential determinants of left ventricular mass, much of the support for such relationships has been derived indirectly [8] or from in vitro studies [40, 41]. In vivo studies in man, with or without hypertension, have been less impressive [28, 42]. In the present study there was no consistent difference in angiotensin II, catecholamines or plasma insulin between groups with and without LVH.

Gender differences in left ventricular mass and racial differences in Na-Li CT [43] do not invalidate the cross-sectional comparisons of matched groups in the present study.

A peripheral finding in this study was the independent contribution of diabetes to impaired diastolic filling. Similar findings have been published for nor- motensive subjects with insulin-dependent diabetes [44], and could reflect the increased myocardial interstitial fibrosis described even in some normotensive diabetic subjects without coronary artery disease $[45$, 46]. Whether this impaired diastolic dysfunction related to the diabetic state per se could contribute to their excess mortality after myocardial infarction [47] warrants further study.

In conclusion, this study has demonstrated that a subgroup of both normotensive control subjects and subjects with NIDDM have mild degrees of LVH. This subgroup is characterised by elevated mean rates of $\mathrm{Na}-\mathrm{Li}$ CT compared to those without, and does not otherwise differ in any clinical, biochemical or echocardiographic parameter. This suggests for the first time an independent association between $\mathrm{LVH}$, cardiovascular risk and elevated rates of $\mathrm{Na}$ $\mathrm{Li}$ CT in normotensive subjects with and without NIDDM.

Acknowledgements. We are grateful to Dr. V.Mohamed-Ali, Nadia Payne, Sheona Gillies and Elin Carstensen for performing the assays, and to Dr. D. Patterson for advice.

\section{References}

1. Casale PN, Devereux RB, Milner M et al. (1986) Value of echocardiographic measurement of left ventricular mass in predicting cardiovascular morbid events in hypertensive men. Ann Intern Med 105: 173-178

2. Silberberg JS, Barre PE, Prichard SS, Sniderman AD (1989) Impact of left ventricular hypertrophy on survival in end stage renal disease. Kidney Int 36: 286-290

3. Levy D, Garrison RJ, Savage DD, Kannel WB, Castelli WP (1989) Left ventricular mass and incidence of coronary heart disease in an elderly cohort. Ann Intern Med 79: 291-293

4. Koren MJ, Devereux RB, Casale PN, Savage DD, Laragh JH (1991) Relation of left ventricular mass and geometry to morbidity and mortality in uncomplicated essential hypertension. Ann Intern Med 114: 345-352

5. Rosengren A, Welin L, Tsipogianni A, Wilhelmsen L (1989) Impact of cardiovascular risk factors on coronary heart disease and mortality among middle aged diabetic men: a general population study. BMJ 299: 1127-1131

6. Galderisi M, Anderson KM, Wilson PWF, Levy D (1991) Echocardiographic evidence for the existence of distinct diabetic cardiomyopathy. Am J Cardiol 68: 85-89

7. Savage DD, Levy D, Dannenberg AL, Garrison RJ, Castelli WP (1990) Association of echocardiographic left ventricular mass with body size, blood pressure and physical activity (The Framingham study). Am J Cardiol 65: 371-376

8. Devereux RB, Pickering TG, Cody RJ, Laragh JH (1987) Relation of renin angiotensin system to left ventricular hypertrophy and function in experimental and human hypertension. J Clin Hypertension 3: 87-103

9. Corea L, Bentivoglio M, Verdecchia P, Motolese M (1982) Left ventricular wall thickness and plasma catecholamines in borderline and stable essential hypertension. Eur Heart J 3: $164-170$

10. Sasson Z, Rasooly Y, Bhesania T, Rasooly T (1993) Insulin resistance is an important determinant of left ventricular mass in the obese. Circulation 88: 1431-1436 
11. Yap L, Arrazola A, Soria F, Diez J (1989) Is there increased cardiovascular risk in essential hypertensive patients with abnormal kinetics of red blood cell sodium-lithium countertransport. J Hypertension 7: 667-673

12. WHO Study Group (1985) Diabetes mellitus. WHO Technical Report Series. No 727. Geneva

13. White WB (1990) Predicting hypertensive heart disease via non-invasive methodology: relationship between ambulatory blood pressure and cardiac indices derived by echocardiography and radionuclide ventriculography. J Hypertension 8: s113-s 118

14. Devereux RB, Campo E, Sachs I, Reicheck N (1986) Echocardiographic assessment of left ventricular hypertrophy: comparison to necropsy findings. Am J Cardiol 57: 450-458

15. Levy D, Savage DD, Garrison RJ et al. (1987) Echocardiographic criteria for left ventricular hypertrophy: the Framingham heart study. Am J Cardiol 67: 956-960

16. Rokey R, Kuo LC, Zoghbi WA, Limacher MC, Quinones MA (1985) Determination of parameters of left ventricular diastolic filling with pulsed Doppler echocardiography: comparison with cineangiography. Circulation 71: 543-550

17. Friedewald WT, Levy RI, Frederickson DS (1972) Estimation of the concentration of low density lipoprotein cholesterol in plasma without the use of the preparative ultracentrifuge. Clin Chem 18: 499-502

18. Mohamed-Ali V, Yudkin JS (1992) An end point amplified enzymo immunoassay (IEMA) specific for human insulin. Clin Sci 82 [Suppl 27]: 48

19. Dusterdieck G, McElwee G (1971) Estimation of angiotensin II concentration in human plasma by radioimmunoassay. Some applications to physiological and clinical states. Eur J Clin Invest 2: 32-38

20. Carstensen E, Yudkin JS (1994) Platelet catecholamine concentrations after short term stress in normal subjects. Clin Sci 86: 35-41

21. Foyle WJ, Drury PL (1991) Reduction of Li-Na countertransport by physiological levels of insulin in vitro. $\mathrm{J}$ Hypertens 9: 713-717

22. Canessa M, Adragna N, Solomon HS, Connolly TM, Tocheson DC (1980) Increased sodium-lithium countertransport in red cells of patients with essential hypertension. New Eng J Med 302: 772-776

23. Gould MM, Mohamed-Ali V, Goubet SA, Yudkin JS, Haines AP (1993) Microalbuminuria: associations with height and sex in non-diabetic subjects. BMJ 306: 240-242

24. Levy D, Anderson KM, Savage DD et al. (1988) Echocardiographically detected left ventricular hypertrophy: prevalence and risk factors. Ann Intern Med 108: 7-13

25. Gambardella S, Frontoni S, Spallone V et al. (1993) Increased left ventricular mass in normotensive diabetic patients with autonomic neuropathy. Am J Hypertension 6: 97-102

26. Nosadini R, Semplicini A, Fioretto P et al. (1991) Sodiumlithium counter transport and cardiorenal abnormalities in essential hypertension. Hypertension 18: 191-198

27. Saito T, Kai N, Yamamoto N et al. (1993) Cardiovascular response and red cell membrane sodium transport in hypertensive cardiac hypertrophy. J Hum Hyper 7: 485-489

28. Weder AB, Schork NJ, Krause L, Julius S (1991) Red blood cell lithium-sodium transport in the Tecumseh blood pressure study. Hypertension 17: 652-660

29. Schieken RM, Clarke WR, Lauer RM (1981) Left ventricular hypertrophy in children with blood pressures in the upper quintile of the distribution. The Muscatine study. Hypertension 3: 669-675

30. Rutherford PA, Thomas TH, Wilkinson R (1992) Erythrocyte sodium-lithium countertransport: clinically useful, pathologically instructive or just phenomenology? Clin Sci 82: 341-352

31. Trevisan R, Cipollina MR, Duner E et al. (1993) Increased alkalinising effect of insulin and angiotensin II on fibroblasts from hypertensive and microalbuminuric type 2 (non-insulin-dependent) diabetic patients. Diabetologia 36 [Suppl 1] A 34 (Abstract)

32. England BK, Chastain JL, Mitch WE (1991) Abnormalities in protein synthesis and degradation induced by extracellular pH in BC3111 myocytes. Am J Physiol 260: C277-C281

33. Maly K, Hochleitner BW, Grunicke H (1990) Interrelationship between growth factor-induced activation of the $\mathrm{Na}-\mathrm{H}$ antiporter and mobilisation of intracellular calcium in N1H3T3 fibroblasts. Biochem Biophys Res Commun 167: 1206-1213

34. Thibonnier M, Bayer AL, Simonson MS, Douglas JG (1992) Effects of amiloride analogues on AVP-binding and activation of V1 receptor expressing cells. Am J Physiol 262: E76-E 86

35. Semplicini A, Lusiani L, Marzola M et al. (1992) Erythrocyte $\mathrm{Li}+/ \mathrm{Na}+$ and $\mathrm{Na}+/ \mathrm{H}+$ exchange, cardiac anatomy and function in insulin dependent diabetics. Eur J Clin Invest 22: 254-259

36. Mahoney LT, Schieken RM, Clarke WR, Lauer RM (1988) Left ventricular hypertrophy and exercise responses predict future blood pressure. The Muscatine Study. Hypertension 65: 1192-1197

37. DeSimone G, Devereux RB, Schlussel Vet al. (1990) Echocardiographic left ventricular mass predicts risk of developing subsequent borderline hypertension. J Am Coll Cardiol 15: $14-18$

38. Nielsen JR, Oxhoj H (1985) Echocardiographic variables in progeny of hypertensive and normotensive parents. Acta Med Scand 693 [Suppl]: 61-64

39. Boerwinkle $\mathrm{E}$ (1986) Analysis of the distribution of erythrocyte sodium lithium countertransport in a sample representative of the general population. Genet Epidemiol 3: 365-378

40. Simpson P (1983) Norephinephrine stimulated hypertrophy of cultured rat myocardial cell is an alpha-adrenergic response. J Clin Invest 72: 732-738

41. Griffin SA et al. (1991) Angiotensin II causes vascular hypertrophy by a non-pressor mechanism. Hypertension 17: 626-635

42. Sierra A, Coca A, Pare JC et al. (1993) Erythrocyte ion fluxes in essential hypertensive patients with left ventricular hypertrophy. Circulation 88: 1628-1633

43. Trevisan M, Ostrow D, Cooper RS, Sempos C, Stamler J (1984) Sex and race differences in sodium-lithium countertransport and red cell sodium concentration. Am J Epidemiol 120: 537-541

44. Paillole C, Dahan M, Paycha F et al. (1989) Prevalence and significance of left ventricular filling abnormalities determined by Doppler echocardiography in young type 1 (insulin dependent) diabetic patients. Am J Cardiol 64: 10101016

45. Genda A, Mizuno S, Nunoda S et al. (1986) Clinical studies on diabetic myocardial disease using exercise testing with myocardial scintigraphy and endomyocardial disease. Clin Cardiol 9: 375-382

46. Nunoda S, Genda A, Sugihara N, Nakayama A, Mizone S, Takeda R (1985) Quantitative approach to the histopathology of the biopsied right ventricular myocardium in patients with diabetes mellitus. Heart and Vessels 1: 43-47

47. Lynch M, Gammage MD, Lamb P, Nattrass M, Pentecost BL (1994) Acute myocardial infarction in the thrombolytic era. Diabet Med 11: 162-166 